\title{
A survey of mercury content in pig tissues carried out in the Czech Republic during years 2015-2019
}

\author{
Martin Svoboda ${ }^{1}$, Jiří Bureš², Jiří Drápal ${ }^{3}$, Kristýna Geboliszováa ${ }^{4}$ Danka Haruštiaková5, \\ Leona Nepejchalová ${ }^{2}$, Marie Skočovská ${ }^{4}$ Zdeňka Svobodová ${ }^{7}$ \\ ${ }^{1}$ University of Veterinary Sciences Brno, Faculty of Veterinary Medicine, Ruminant and Swine Clinic, \\ Brno, Czech Republic \\ ${ }^{2}$ Institute for State Control of Veterinary Biologicals and Medicines, Brno, Czech Republic \\ ${ }^{3}$ Central Veterinary Administration of the State Veterinary Administration, Prague, Czech Republic \\ ${ }^{4}$ University of Veterinary Sciences Brno, Faculty of Veterinary Medicine, Large Animal Clinical Laboratory, \\ Brno, Czech Republic \\ ${ }^{5}$ Masaryk University, Faculty of Medicine, Institute of Biostatistics and Analyses, Brno, Czech Republic \\ ${ }^{6}$ Masaryk University, Faculty of Science, RECETOX, Brno, Czech Republic \\ ${ }^{7}$ University of Veterinary Sciences Brno, Faculty of Veterinary Hygiene and Ecology, \\ Department of Animal Protection and Welfare and Veterinary Public Health, Brno, Czech Republic
}

Received November 4, 2020

Accepted August 31, 2021

\begin{abstract}
The assessment of mercury content in the muscle, liver and kidneys of fattening pigs and sows was conducted in the Czech Republic during the period of 2015-2019. The samples were collected from sows $(n=31)$ and fattening pigs $(n=210)$. The average mercury content in muscle, liver, and kidneys of sows over 5 years was $0.00057 \pm 0.00004,0.0045 \pm 0.0008$, and $0.0224 \pm 0.0067 \mathrm{mg} \cdot \mathrm{kg}^{-1}$, respectively. The average mercury content in muscle, liver, and kidneys of fattening pigs over the same period was $0.00059 \pm 0.00004,0.0012 \pm 0.0001$, and $0.0044 \pm 0.0004 \mathrm{mg} \cdot \mathrm{kg}^{-1}$, respectively. The maximum residual limit (MRL) for human consumption was exceeded in 14 kidney samples. The mercury content in liver did not differ significantly between sows and fattening pigs; in kidneys, the mercury content was higher in sows, with a significant difference in one year $(P<0.05)$. A slight decrease in the mercury content in kidneys and liver was observed in fattening pigs from the year 2015. In sows, there was a significant increase in the mercury content in kidneys in the year 2016. It can be concluded that there is a need for further monitoring of the mercury content in pig tissues in the Czech Republic.
\end{abstract}

Swine, kidney, liver, sow, fattening pig

Mercury is one of the most toxic metal elements that contaminate the environment both due to natural processes and due to anthropogenic activity (Martinez-Finley and Aschner 2014).

Both humans and animals can be exposed to various forms of mercury during their lifetimes. Inhalation of mercury vapor from the air, swallowing small particles of mercury from amalgam dental fillings, mercury intake from water and contaminated foods are mentioned as possible routes of mercury delivery to humans (Pirrone et al. 2001).

Mercury occurs in several different forms: as metallic (elemental) mercury, inorganic, and organic (methylmercury). In particular, inorganic mercury compounds cause kidney damage (Taugner et al. 1966).

Methylmercury is much more toxic than the inorganic form; it damages the central nervous system and is neurotoxic. Especially at risk are pregnant women as mercury in the form of methylmercury passes through the placenta into the foetus (Clarkson et al. 2007). The consequences of the neurotoxic effects of mercury are neuropsychiatric disorders in children, for example, mental retardation and developmental defects, visual and hearing

Address for correspondence:

Doc. MVDr. Martin Svoboda, Ph.D.

Ruminant and Swine Clinic

Faculty of Veterinary Medicine

University of Veterinary Sciences Brno

Palackého tř. 1946/1, 61242 Brno, Czech Republic

Phone: + 420541562433

E-mail: svobodama@vfu.cz

http://actavet.vfu.cz/ 
disorders, or impaired speech and memory (Haley 2005). A case of mercury poisoning in humans after having eaten pork meat from a pig that was fed with methyl mercury-dressed seed grain was described in New Mexico (Curley et al. 1971).

The uptake of methylmercury by consumption of fish and fish products is currently considered to be the most important source of mercury exposure to humans (Bernhoft 2012).

Consumption of pig tissues can also represent a source of mercury for people due to the use of fishmeal for feed purposes. Another factor to consider is the use of thiomersal, which contains ethylmercury and is used as a preservative in some vaccines for livestock (EFSA 2008; ÚSKVBL 2014).

The aim of the present paper was to analyse and present the results of a study of mercury content in pig tissues carried out in the framework of a state monitoring programme during the years 2015-2019 in the Czech Republic.

\section{Materials and Methods}

Samples of pig tissues were collected by the Czech State Veterinary Administration within a national plan for the monitoring of residues and contaminants in accordance with the Council Directive 96/23/EC (1996) in the years 2015-2019. The minimum number of animals for a year from which tissue samples were taken was calculated according to the methodology of the aforementioned directive.

Veterinary inspectors selected randomly slaughtered fattening pigs and sows for tissue sampling at various slaughterhouses in the Czech Republic. Pigs for fattening were slaughtered in the usual slaughter weight of about $90-110 \mathrm{~kg}$ at the age of 6 to 7 months. The goal was to cover as large an area as possible. Samples included muscle (lean meat), any part of the liver (sample of at least $0.5 \mathrm{~kg}$ ), and the whole kidney.

The determination was carried out in the laboratories of the State Veterinary Institutes in the Czech Republic. All laboratories have been accredited according to EN ISO/IEC 17025 and regularly participate in inter-laboratory comparison tests. The methods used were validated and the quality of routine analyses was controlled by a testing of reference, duplicate, and blank samples.

The content of total mercury (THg) in tissues was determined by the cold vapour atomic absorption spectrometry on an AMA 254 analyser (Altec Ltd., Dvůr Králové nad Labem, Czech Republic) with a limit of quantification (LOQ) of $0.001 \mathrm{mg} \cdot \mathrm{kg}^{-1}$ (at a sample weight of $50 \mathrm{mg}$ ) for muscle, liver, and kidneys. The samples were thawed, weighed, put into combustion boats and inserted into the AMA 254 without any sample preparation.

Data manipulation and statistical analysis

The number of analysed samples varied from 4 to 46 for sows/fattening pigs in different years. The mercury content in muscle tissue was found to be below the LOQ in almost all samples, making a statistical comparison impossible. For the purposes of statistical calculations, the values below the LOQ were replaced by half of this limit, i.e. by the value of $0.0005 \mathrm{mg} \cdot \mathrm{kg}^{-1}$. The differences in the mercury content between years, sows/fattening pigs and liver/kidney were analysed using the factorial ANOVA followed by Fisher's post hoc test for unequal N. The evaluation of time trends was performed using the Pearson correlation coefficient. $P<0.05$ was considered significant in all tests. Data manipulation and statistical analysis were performed using Statistica, version 13 (TIBCO Software Inc.).

\section{Results}

The mercury concentration in muscle tissue was below LOQ $\left(<0.001 \mathrm{mg} \cdot \mathrm{kg}^{-1}\right.$ of wet weight $)$ in 28 from 31 samples from sows, and in 201 from 210 samples from fattening pigs. The remaining three and nine values resulted in a mean value of $0.0012 \mathrm{mg} \cdot \mathrm{kg}^{-1}$ and $0.0025 \mathrm{mg} \cdot \mathrm{kg}^{-1}$ for sows and fattening pigs, respectively. The maximum residual limit (MRL) for human consumption (MRL for mercury in muscle: $0.010 \mathrm{mg} \cdot \mathrm{kg}^{-1}$ ) was not exceeded in any sample.

The mercury content in liver and kidney of sows and fattening pigs during 2015-2019 is presented in Table 1 and Fig. 1. The mercury content found in liver varied between $<0.001$ and $0.0170 \mathrm{mg} \cdot \mathrm{kg}^{-1}$ of wet weight and did not exceed the MRL for human consumption in any sample (MRL for mercury in liver: $0.020 \mathrm{mg} \cdot \mathrm{kg}^{-1}$ ). The mercury concentrations in the kidneys ranged from $<0.001$ to $0.2060 \mathrm{mg} \cdot \mathrm{kg}^{-1}$ of wet weight. The MRL for human consumption (MRL for mercury in kidney: $0.020 \mathrm{mg} \cdot \mathrm{kg}^{-1}$ ) was exceeded in 14 samples: 10 of them in sows (one in 2015 and 2017, two in 2016, and three in 2018 and 2019 each) and 4 of them in fattening pigs (one each in 2015, 2017, 2018 and 2019) (Table 1). 

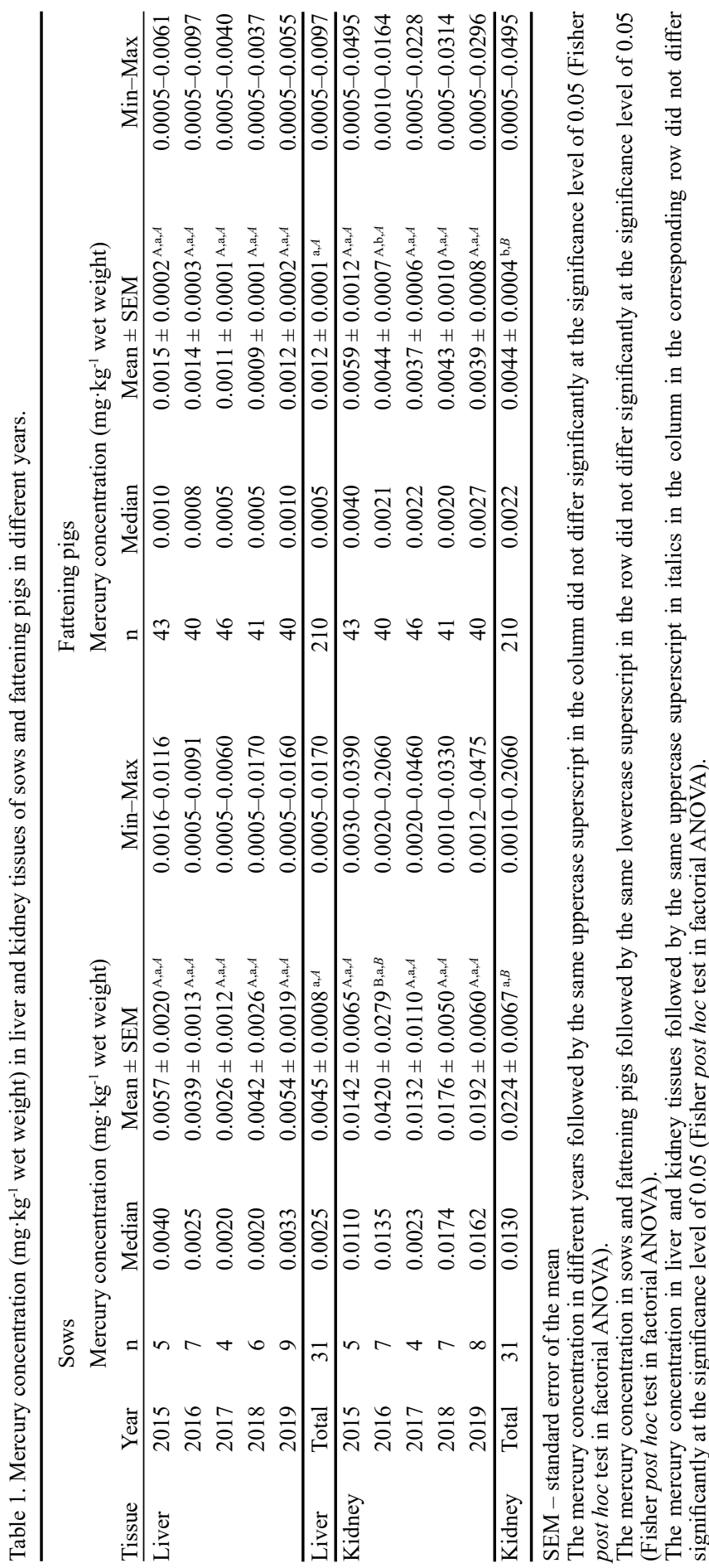

The mercury concentration was significantly affected by the age category of pigs (sows/fattening pigs) (factorial ANOVA, the effect of the age category: $F(1,462)$ $=51.377, P<0.001$ ), tissue (factorial ANOVA, the effect of tissue: $\mathrm{F}(1,462)=52.081$, $P<0.001)$ as well as by the year (factorial ANOVA, the effect of year: $\mathrm{F}(4,462)=3.897$, $P=0.004)$. The significance of all effects is the result of a high value of mercury in the kidneys of sows in 2016. Indeed, the mercury concentration in liver did not differ significantly between sows and fattening pigs in any particular year. A different situation was observed in kidney, where the mercury concentration differed significantly between sows and fattening pigs in 2016, being higher in sows. The differences between liver and kidney were significant only in one case, in sows in 2016. Year-over-year differences were confirmed only in the kidneys of sows, which showed significantly higher values in 2016 (Table 1, Fig. 1).

Although the general effect of year was significant, no significant decrease in the mercury concentration in tissues was observed during the time period (the correlation coefficient between the mean mercury concentration and year varied from -0.759 to $-0.025, P>0.05$ in all cases). 


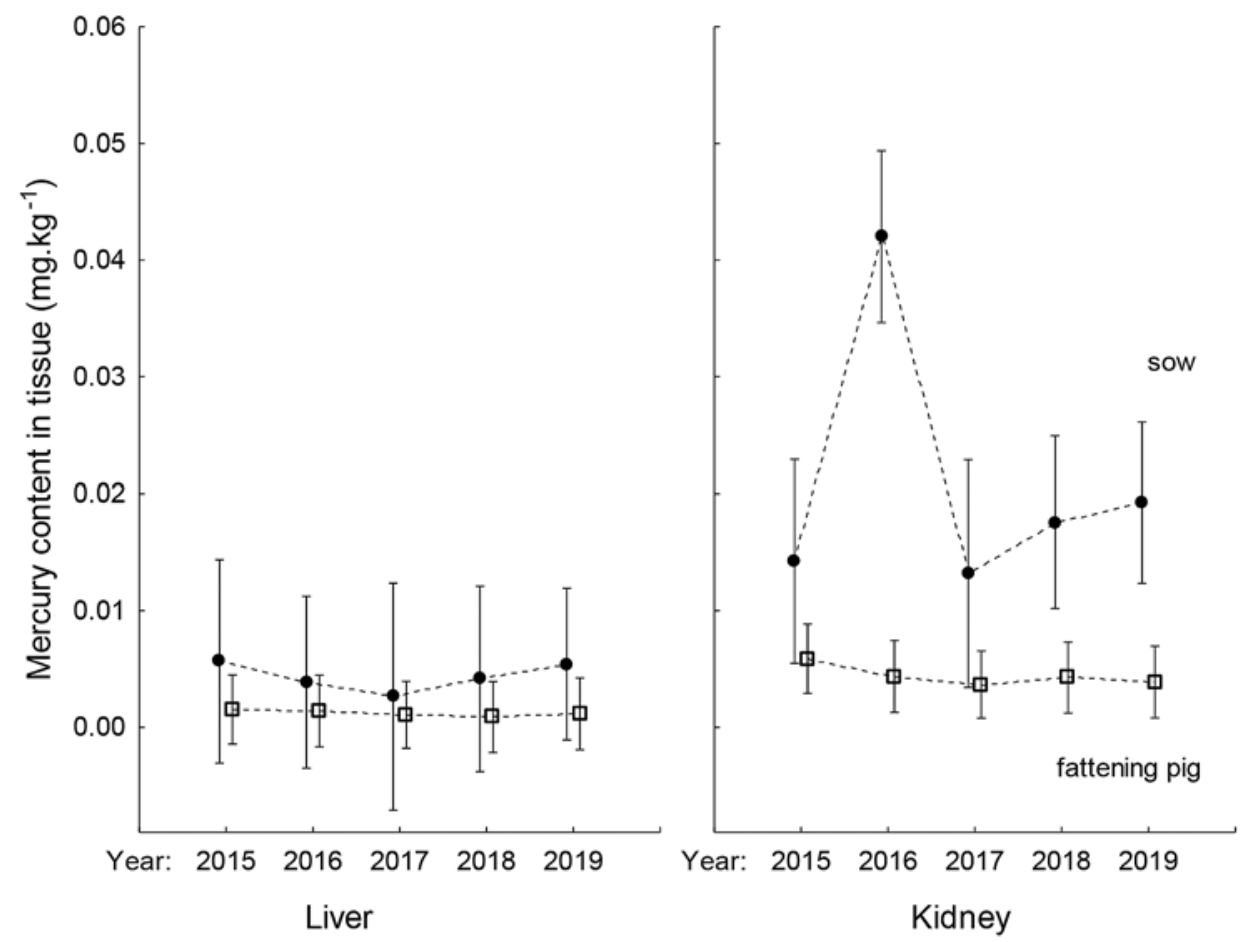

Fig. 1. Mercury concentration in liver and kidney tissues of sows and fattening pigs during 2015-2019 (mean and 0.95 confidence interval).

- sow; $\square$ fattening pig

\section{Discussion}

The environment is contaminated with mercury from both natural and anthropogenic sources (Saturday 2018). Natural sources include mercury release from volcanoes, forest fires, weathering of rocks and geological movements (Sund seth et al. 2017). Anthropogenic sources of mercury in the environment are mainly combustion coal and waste. Mercury also enters the environment from industrial activities, e.g. the manufacturing of electrical equipment, dyes, batteries or fluorescent lamps, paper, cosmetics and pharmaceutical industry (Pirrone et al. 2001).

Mercury is deposited in soil, water and sediments where it is transformed by microbiota and microfauna (methylation) into the more toxic organic form of methylmercury (Morel et al. 1998). Because mercury methylation occurs almost exclusively in aquatic systems, waterfowl and fish species usually contain much higher amounts of mercury than terrestrial animals (Ulrich et al. 2001). Therefore, the consumption of fish and fish products is currently considered to be the most important source of mercury exposure to humans (Martinez-Finley and Aschner 2014). Methylmercury can make up a significant part of the total amount of mercury contained in fish and fishery products. For instance, Marshall (1989) found that methylmercury comprised $81 \%$ of the total mercury content in fishmeal. In feedstuffs other than fish and fishery products, mercury is mainly found in other forms than methylmercury, predominantly in the form of inorganic mercury which is considered less hazardous (EFSA 2008). 
However, consumption of pig tissues can also represent a source of organic mercury to humans because of the use of fishmeal in pig diets. Another source of organic mercury from pig tissues can be the use of thiomersal which contains ethylmercury. This substance is still used as a preservative in some vaccines for livestock (EFSA 2008; ÚSKVBL 2014).

Another factor to consider is the dust sediment present in pig stables. According to Ulrich et al. (2001), mercury detected in dust sediments apparently did not contribute significantly to their content in animal tissues. They found that the concentration of mercury in barn dust sediments followed its concentration in feed mixtures. The authors therefore assumed that feed mixtures were the major source of mercury found in dust sediments.

Mercury can occur in tissues of pigs in inorganic as well as in organic chemical forms. Inorganic mercury salts are not fat soluble and therefore do not pass in this form the bloodbrain barrier or the placental barrier. Inorganic mercury is taken up in the liver, but the organ with the highest concentrations of inorganic mercury is the kidneys, especially the area of proximal tubules, which is the main target site for mercury accumulation in this organ (Berlin and Ullberg 1963; Taugner et al. 1966; Lohren et al. 2015).

The most important organic form is methylmercury. Compared to inorganic forms, methylmercury is absorbed after oral ingestion to a much larger extent, and also faster (Norseth and Clarkson 1971). Methylmercury is liposoluble and it can easily cross cell membranes, including the placental and blood-brain barriers (Clarkson et al. 2007). Gyrd-Hansen (1981) evaluated the toxicokinetics of methylmercury in pigs. He found that the highest mercury concentrations were detected in kidney and liver. The concentrations in muscle were approximately half as high as those in the liver. Mercury was eliminated much slower from muscles than from the blood, and in liver and kidneys the mercury concentrations after 6 weeks were almost identical. This indicates a very long half-life of methylmercury in liver and kidneys.

Ethylmercury represents another form of organic mercury. This form of mercury is likely to be converted to inorganic forms in tissues to a larger extent than methylmercury. Its high concentrations are found in liver and kidney, and a low amount in muscle tissues (Gyrd-Hansen and Helleberg 1976).

In general, regardless of their chemical form, all the mentioned mercury compounds have a similar pattern of distribution in tissues. In particular, the kidneys of animals with a longer breeding season can accumulate significant amounts of mercury.

In our study, the average mercury concentrations were higher in the kidneys and the liver compared to the muscles, in which the mercury concentrations were the lowest. This is in agreement with the study of Drápal and Haldová (2014).

It is beyond the scope of this article to distinguish which forms of mercury were present in the analysed pig tissues. Although chromatographic techniques are available for differentiating organic $\mathrm{Hg}$ from its inorganic form, they are not routinely used, as they are complicated and costly (EFSA 2008). Therefore, only the total Hg content was determined in our study.

Marshall (1989) found that when fishmeal was included in the diet, methylmercury residues increased significantly in all tissues in relation to the concentrations found in fishmeal-free diets. The proportion of methylmercury to the total mercury in muscle tissue of pigs fed fishmeal was found to be $81.4 \%$. This confirmed that the source of mercury residues in muscles was derived primarily from fishmeal.

In our study, there was a slight decrease in the kidney and liver mercury concentrations in fattening pigs from the year 2015. This is in agreement with literature data, in which a tendency for decreasing mercury concentrations in animal tissues has been documented (Falandysz 1993; López-Alonso et al. 2007). In the most recent study, Nawrocka et al. (2020) did not confirm the decreasing trends of $\mathrm{Hg}$ concentrations in pig's liver from 2009 to 2018, although their values were lower than those reported by other authors from Poland in previous decades. 
The decreasing tendency could be attributed to several factors: currently no mercurycontaining pesticides or biocides are allowed for agricultural use in our country. The use of fishmeal in pig diets is not so frequent due to its price. The manufacturer of the preparation for the immunocastration of boars (Improvac) agreed to replace the thiomersal preservative containing ethylmercury for another mercury-free preservative preparation (chlorocresol).

We have found higher mercury accumulation in the kidneys of sows compared to fattening pigs. This can be explained by the tendency of mercury to cumulate in the kidneys (Clarkson et al. 2007) and it is connected with the increasing age of the animals.

For human consumption, the Commission Regulation (EU) 2018/73 has established the MRLs of $0.010 \mathrm{mg} \cdot \mathrm{kg}^{-1}, 0.020 \mathrm{mg} \cdot \mathrm{kg}^{-1}$, and $0.020 \mathrm{mg} \cdot \mathrm{kg}^{-1}$ for the mercury content in the muscle, liver, and kidneys, respectively.

A significant increase in the mercury content in kidneys of sows was found in the year 2016. This shows that despite the positive tendency, the isolated above-limit values of mercury cannot be ruled out. In our study, we found 14 kidney samples to be above the MRL, with the majority of such samples being from sows.

It can be concluded that the above-limit mercury concentrations can rarely be found in the kidneys, especially in the elderly categories of pigs. Based on our results, it can be stated that there is still a need for further monitoring of the mercury content in pig tissues in the Czech Republic.

\section{Acknowledgements}

The authors thank the Central Veterinary Administration of the State Veterinary Administration for providing the results of the examination of contaminants from the database of the Professional Information System.

This research was supported by the Internal Creative Agency FVL/Illek/ITA2019, University of Veterinary and Pharmaceutical Sciences Brno, Czech Republic.

Further support was provided by the RECETOX research infrastructure (Ministry of Education, Youth and Sports of the Czech Republic; LM2018121) and CETOCOEN EXCELLENCE Teaming 2 project (Horizon 2020; 857560 and Ministry of Education, Youth and Sports of the Czech Republic; 02.1.01/0.0/0.0/18_046/0015975).

\section{References}

Berlin M, Ullberg S 1963: Accumulation and retention of mercury in the mouse. I. An autoradiographic study after a single intravenous injection of mercuric chloride. Arch Environ Health 6: 589-601

Bernhoft RA 2012: Mercury Toxicity and Treatment: A Review of the Literature. J Environ Public Health 2012: 1-10

Clarkson TW, Vyas JB, Ballatori N 2007: Mechanisms of mercury disposition in the body. Am J Ind Med 50: 757-764

Commission Regulation (EU) 2018/73 of 16 January 2018 amending Annexes II and III to Regulation (EC) No 396/2005 of the European Parliament and of the Council as regards maximum residue levels for mercury compounds in or on certain products. OJ L 13, 18.1.2018, pp. 8-20

Council Directive 96/23/EC of 29 April 1996 on measures to monitor certain substances and residues thereof in live animals and animal products and repealing Directives 85/358/EEC and 86/469/EEC and Decisions 89/187/EEC and 91/664/EEC, OJ L 125, 23.5.1996, pp. 10-32

Curley A, Sedlak VA, Girling EF, Hawk RE, Barthel WF 1971: Organic mercury identified as the cause of poisoning in humans and hogs. Science 172: 65-67

Drápal J, Haldová S 2014: Mercury content in the meat and organs of cattle and pigs. Maso International 4: 87-90

EFSA 2008: Opinion of the Scientific Panel on Contaminants in the food chain on a request from the European Commission on mercury as undesirable substance in feed. EFSA J 654: 1-76

Falandsyz J 1993: Some toxic and essential trace metals in swine from Northern Poland. Sci Total Environ 136: 193-204

Gyrd-Hansen N, Helleberg A 1976: Methoxyethyl mercury toxicity in pigs: kidney function and mercury distribution. Acta Pharmacol Toxicol 38: 229-240

Gyrd-Hansen N 1981: Toxicokinetics of methyl mercury in pigs. Arch Toxicol 48: 173-181

Haley BE 2005: Mercury toxicity: genetic susceptibility and synergistic effects. Medical Veritas: J Med Truth 2: 535-542

Lohren H, Blagojevic L, Fitkau R, et al. 2015: Toxicity of organic and inorganic mercury species in differentiated human neurons and human astrocytes. J Trace Elem Med Biol 32: 200-208 
López-Alonso M, Miranda M, Castillo C, Hernández J, García-Vaquero M, Benedito JL 2007: Toxic and essential metals in liver, kidney and muscle of pigs at slaughter in Galicia, north-west Spain. Food Addit Contam 24: 943-954

Marshall BL 1989: Mercury residues in the tissues of domestic pigs and feral animals in New Zealand. Surveillance 16: $17-22$

Martinez-Finley EJ, Aschner M 2014: Recent advances in mercury research. Curr Environ Health Reports 1: 163-171

Morel FM, Kraepiel AM, Amyot M 1998: The chemical cycle and bioaccumulation of mercury. Annual Rev Ecol Sys 29: 543-566

Nawrocka A, Durkalec M, Szkoda J, Filipek A, Kmiecik M, Żmudzki J, Posyniak A 2020: Total mercury levels in the muscle and liver of livestock and game animals in Poland, 2009-2018. Chemosphere 258: 1-12

Norseth T, Clarkson TW 1971: Intestinal transport of 203Hg-labeled methyl mercury chloride. Role of biotransformation in rats. Arch Environ Health 22: 568-577

Pirrone N, Costa P, Pacyna JM, Ferrara R 2001: Mercury emissions to the atmosphere from natural and anthropogenic sources in the Mediterranean region. Atmos Environ 35: 2997-3006

Saturday A 2018: Mercury and its associated impacts on environment and human health: A review. J Environ Health Sci 4: 37-43

Sundseth K, Pacyna JM, Pacyna EG, Pirrone N, Thorne RJ 2017: Global sources and pathways of mercury in the context of human health. Int J Environ Res Public Health 14: 105

Taugner R, Winkel K, Iravani J 1966: The localization of mercuric chloride concentration in the rat kidney. Virchows Archiv 340: 369-383

Ulrich R, Raszyk J, Nápravník A 2001: Variations in contamination by mercury, cadmium and lead on swine farms in the district of Hodonin in 1994 to 1999 . Vet Med 46: 132-139

ÚSKVBL 2014: Nastavení rozhodovacího limitu pro obsah rtuti v ledvinách potravinových zvířat (s výjimkou ryb) (in Czech, Setting a decision limit for mercury in the kidneys of food - producing animals (excluding fish). Ústav pro státní kontrolu veterinárních biopreparátů a léčiv (Institute for State Control of Veterinary Biologicals and Medicines). Available from: http://www.uskvbl.cz/attachments/779 Stanovisko\%20pro\%20 SVS\%202014-srpen.pdf 